\title{
PILOTING THE PRESERVATION/ DEVELOPMENT BALANCE ON THE WILD AND SCENIC RIVERS
}

\author{
INTRODUCTION†
}

In enacting the Wild and Scenic Rivers Act of 1968 (WSRA), ${ }^{1}$ Congress dramatically altered the existimg balance of federal water pohicy. The WSRA's concept was to establish free-flowing river preservation as a necessary coniplement to the previously all-consuming goal of coniprehensive river developnient. ${ }^{2}$ The WSRA vested the power to implenient this new concept in the Departnient of the Interior and the Departnent of Agriculture, both of which were nore preservation-oriented than the federal agencies such as the Federal Energy Regulatory Commission (FERC) that had authorized river developnient projects under the earher regime. Congress thus altered the traditional water resources balance at

$\dagger$ Glossary of terms used in this Note:

- ECPA: Electric Consumer Protection Act of 1986, Pub. L. No. 99-495, 100 Stat. 1243 (codified in scattered sections of 16 U.S.C.).

- ESA: Energy Security Act, Pub. L. No. 96-294, 94 Stat. 611 (1980) (codified as amended in scattered sections of 7 U.S.C., 10 U.S.C., 12 U.S.C., 15 U.S.C., 16 U.S.C., 30 U.S.C., 42 U.S.C., \& 50 U.S.C.).

- FERC: Federal Energy Regulatory Commission, previously known as the Federal Power Commission (FPC).

- FPA: Federal Power Act (formerly Federal Water Power Act), ch. 285, 41 Stat. 1063 (1920) (codified as amended at 16 U.S.C. $\$ \S 791 \mathrm{a}-825 \mathrm{r}$ (1982 \& Supp. IV 1980).

- WSRA: Wild and Scenic Rivers Act, Pub. L. No. 90-542, 82 Stat. 906 (1968) (codified as amended at 16 U.S.C. $\S \S 1271-1287$ (1982 \& Supp. IV 1986)).

- Administering Secretary: Official charged with day-to-day supervision of a national wild and scenic river area. The administering Secretary is the "Secretary of the Interior or, where national forest lands are involved, the Secretary of Agriculture." Id. § 4(a), 82 Stat. at 1058 (codified as amended at 16 U.S.C. $\$ 1275(a)$ (1982)).

- Authorizing Agency: Federal agency that licenses, permits, or otherwise assists in the construction of water resources projects.

- Determining Agency: Agency or Secretary responsible for determining whether a proposed project violates the ECPA or the WSRA.

1. Pub. L. No. $90-542,82$ Stat. 906 (codified as amended at 16 U.S.C. $\S \S 1271-1287$ (1982 \& Supp. IV 1986)) [cited hereinafter as WSRA]. 1988 is the WSRA's twentieth-anniversary year. For a prospective view of the Act's intended effects, see Tarlock \& Tippy, The Wild and Scenic Rivers Act of 1968, 55 CORNELL L. REv. 707 (1970).

2. See M. Reisner, Cadillac Desert 115-24, 179-81 (1987) (chronicling growth of federal involvement in irrigation, hydropower production, and dam building). 
both the macro level of national policy, and the micro level of administrative implementation.

Congress did not, however, immediately succeed in redirecting federal actions to advance its twin goals of river preservation and balanced resource developinent. The traditional authorizing agencies, while paying lip service to those goals, often resisted implementation of the wild and scenic rivers prograin. As recently as 1986-eighteen years after passage of the WSRA - a congressional committee could still coinplain about FERC's hostility to environmental and river preservation concerns. ${ }^{3}$ Courts and agencies have also struggled to imterpret the WSRA in a manner consistent with Congress's goals, but the Act's language has frequently frustrated their efforts. As one federal court of appeals coinplained regarding a crucial section of the WSRA: "The syntax is poor, the language is confusing and at first glance may seem inexplicable." 4 In confronting this inexplicability, some courts have rigorously parsed the Act's language, 5 while others have probed congressional intent. ${ }^{6}$ One agency, purporting to apply the WSRA, has even chosen the wrong substantive standard from those contained in the Act. ${ }^{7}$

To help courts and agencies pilot their way toward the ultimate congressional goals of river preservation and balanced development, this Note crafts a scheine of comprehensible standards and presents a viable strategy for enforcing the wild and scemic rivers program. First, the Note examines the historical development and evolution of the wild and scenic rivers concept. ${ }^{8}$ Second, the Note considers and resolves the jurisdictional conflict between the authorizing agencies and the Departınents of the Interior and Agriculture over authority to determine whether a proposed project violates the WSRA. ${ }^{9}$ Third, it distills a comprehensive sys-

3. H.R. REP. No. 507, 99th Cong., 2d Sess. 17-18 (1986), reprinted in 1986 U.S. CodE CoNG. \& ADMIN. NEws 2496, 2504-05 ("FERC's treatment under the Federal Power Act and applicable environmental laws of energy conservation, fish and wildlife, recreation, and other non-power factors has been less than satisfactory.").

4. North Carolina v. FPC, 533 F.2d 702, 709 (D.C. Cir.), vacated, 429 U.S. 891 (1976).

5. North Carolina v. FPC provides an example of such parsing: "Careful analysis however discloses the sense of the verbiage. The entire sentence relates to those rivers "listed in [WSRA \$ 5(a)]' ...." Id. Applying this observation, the court demied protection for a state-recommended river under consideration by the Secretary of the Interior.

6. See, e.g., Appalachian Power Co. v. Umited States, 607 F.2d 935, 940-41 (Ct. Cl. 1979) ("Clearly the Wild and Scenic Rivers Act is a statute of general application .... The obvious purpose of Congress was to preserve all of the histed segments . . ."), cert denied, 446 U.S. 935 (1980).

7. Consumers Power Co., Project No. 2599, 55 F.P.C. 468, 471 (1976) (reviewing changes in reservoir operations located outside of wild and scemic river area under direct and adverse effect language rather than appropriate invade or unreasonably dimimish language).

8. See infra notes $13-72$ and accompanying text.

9. See infra notes 73-98 and accompanying text. 
tem of standards from the relevant statutory language. The Note breaks down each of the standards, analyzes their components, and discusses how they govern agency discretion and further the congressional goals of river preservation and balanced development. ${ }^{10}$ Fourth, the Note examines the statutory and practical limitations on agency enforcement and application of the standards. ${ }^{11}$ Finally, it suggests a direction for legislative reform aimed at overcoming these limitations and facilitating achievement of the congressional goals. ${ }^{12}$

\section{DeVelopment of THE WILd AND SCENIC Rivers CONCEPT}

\section{A. Background.}

The change in federal water policy that Congress sought to effect by enacting the WSRA appears in the contrast between the Act and Congress's prior prodevelopment policy. Congress initiated the prodevelopment policy in 1902 when it passed the Reclamation Act $^{13} \mathrm{~m}$ response to President Theodore Roosevelt's call to reclaim the American West froin the desert through irrigation. ${ }^{14}$ The prodevelopment policy gained further strength in 1920 when Congress passed the Federal Water Power Act (now the Federal Power Act (FPA)). ${ }^{15}$ The Act called for the "comprehensive developinent of the Nation's rivers" and created the Federal Power Commission (now the Federal Energy Regulatory Commission $\left(\right.$ FERC) ${ }^{16}$ ) to superintend the development process. ${ }^{17}$ Congress fixed the prominence of the prodevelopment policy in the 1930s when it authorized damming and control of the great Eastern rivers in response to pressure from President Franklin Roosevelt. ${ }^{18}$

10. See infra notes $99-149$ and accompanying text.

11. See infra notes $150-74$ and accompanying text.

12. See infra pp. 1077-78.

13. Ch. 1093, 32 Stat. 388 (1902) (codified as amended in scattered sections of 43 U.S.C.).

14. See A Bill to Reserve Certain Public Lands for a National Wild Rivers System, to Provide a Procedure for Adding Additional Public Lands and Other Lands to the System, and for Other Purposes, 1967: Hearings on S. 119 and S. 1092 Before the Senate Comm. on Interior and Insular Affairs, 90th Cong., 1st Sess. 45 (1967) [hereinafter 1967 Senate Hearings] (statement of Stewart L. Udall, Secretary of the Interior). As Secretary Udall noted, "We saw a great decision made under President Teddy Roosevelt, in 1902 when the Reclamation Act was passed, and the Nation set out to reclaim the rivers of the West for purposes of irrigation." Id.; see also M. REISNER, supra note 2, at 115-24 (discussing social and political circumstances surrounding passage of Reclamation Act).

15. Ch. 285, 41 Stat. 1063 (1920) (codified as amended at 16 U.S.C. \$§ 791a-825r (1982 \& Supp. IV 1986)) [cited hereinafter as FPA].

16. Department of Energy Organization Act, Pub. L. No. 95-91, § 402, 91 Stat. 565, 583 (1977) (codified at 42 U.S.C. $\$ 7172$ (1982)) (transferring functions from FPC to FERC).

17. FPA, ch. 285, § 10(a), 41 Stat. at 1068 (codified as amended at 16 U.S.C. $\S 803$ (a) (1982)).

18. "I think we saw another historic development in the 1930's under President Franklin Roosevelt, when we appropriated inoney and went on the main stein of our great rivers, and began to build large river control structures." 1967 Senate Hearings, supra note 14, at 45 (statement of 
The policy was supported by a network of authorizing agencies, including the Federal Power Commission (FPC), the Bureau of Reclanation, and the Army Corps of Engineers. Together, these agencies became the principal regulators of the nation's waterways and a powerful force in favor of continued development and exploitation of rivers for hydropower, irrigation, flood control, and navigation. ${ }^{19}$

Despite the strength and pervasiveness of the prodevelopinent policy, an undercurrent of opinion in favor of river preservation arose with the growing environmental awareness and disillusionment with development of the mid-1960s and early 1970s. ${ }^{20}$ The first significant appearance of the wild and scenic rivers concept occurred in 1962, when the Outdoor Recreation Resources Review Committee endorsed river preservation. ${ }^{21}$ Interest grew in 1965, when President Lyndon Johnson urged Congress to "preserve free flowing stretches of our great scenic rivers."22 Although such measures as the Ozark National Scenic Riverways Act ${ }^{23}$ provided a partial solution, proponents of river preservation sought a comprehensive and systematic approach. ${ }^{24}$

But reclamation associations, various beneficiaries of federal water projects, and occasionally a state water control board, vigorously opposed the idea of a comprehensive preservation effort. ${ }^{25}$ These groups warned that preservation neasures resulting in single-use rivers would "seriously infringe upon the long established concept of multiple use of land and water resources ... without sufficient consideration of the value

Secretary Udall); see also Tarlock \& Tippy, supra note 1, at 708-09 (dominant concepts of period were "systematic and efficient resource development" and "government financing and construction of large-scale water developments").

19. See generally M. REISNER, supra note 2 (describing how interagency competition spurred water resources development).

20. This period saw the passage of such landmark environmental legislation as the Wilderness Act, Pub. L. No. 88-577, 78 Stat. 890 (1964) (codified as amended at 16 U.S.C. $\$ \S 1131-1136$ (1982 \& Supp. IV 1986)), the National Environmental Policy Act of 1969, Pub. L. No. 91-190, 83 Stat. 852 (1970) (codified as amended at 42 U.S.C. $\$ \S 4321,4331-4335,4341-4347$ (1982 \& Supp. IV 1986)), and the Endangered Species Act of 1973, Pub. L. No. 93-205, 87 Stat. 884 (codified as amended at 7 U.S.C. $\S 136$ (1982) and in scattered sections of 16 U.S.C.).

21. See To Establish a National Scenic Rivers System, 1968: Hearings on H.R. 8416, H.R. 90, S. 119 and Related Bills Before the Subcomm. on National Parks and Recreation of the House Comm. on Interior and Insular Affairs, 90th Cong., 2d Sess. 120 (1968) [hereinafter 1968 House Hearings] (statement of Edward C. Crafts, Director, Bureau of Outdoor Recreation, Department of the Interior).

22. Id. at 121 (statement of Director Crafts).

23. Pub. L. No. $88-492,78$ Stat. 608 (1964) (codified as amended at 16 U.S.C. $\$ \S 460 \mathrm{~m}$ to 460m-7 (1982)).

24. See 1968 House Hearings, supra note 21, at 53 (statement of Rep. Aspinall, Chairman, Committee on Interior and Insular Affairs) (indicating what he expected from the legislation).

25. See, e.g., 1967 Senate Hearings, supra note 14, at 162-63 (testimony of George Crookham, Chairman, Idaho State Water Resources Board). 
of alternate beneficial uses." 26 The authorizing agencies, despite their status as nominal supporters of river preservation, tacitly supported the prodevelopment position as well.27

\section{B. The Wild and Scenic Rivers Act of 1968.}

Against this background, Congress enacted the WSRA. ${ }^{28}$ Congress signaled its intent to substantially adjust federal water policy to emphasize river preservation and balanced development in its "Congressional Statement of Policy," which captures the spirit of the Act:

[C]ertain selected rivers of the Nation which ... possess outstandingly remarkable scenic, recreational, geologic, fish and wildlife, historic, cultural, or other similar values, shall be preserved in free-flowing condition .... The Congress declares that the established national policy of dam and other construction ... needs to be complemented by a policy that would preserve other selected rivers or sections thereof in their free-flowing condition ....29

\section{Designation of Rivers Under the WSRA-The Macro Balance.} To attain its twin policy goals of river preservation and balanced development, Congress undertook to protect certain rivers and river segments that qualify as "outstandingly remarkable." 30 But Congress lacked suffi-

26. 1968 House Hearings, supra note 21, at 198 (statement of Texas Water Conservation Association); see also id. at 253-54 (statement of James F. Sorenson, President, National Reclamation Association) (opposing legislation because it did not conform to principles of multipurpose development). The opponents thus concluded that the bill "would immediately hazard future development on these designated rivers. In fact it would practically limit the use of the resources of these ... river basins to two purposes-recreation and fish and wildlife." 1967 Senate Hearings, supra note 14, at 162 (testimony of George Crookham, Chairman, Idaho Water Resources Board).

27. See 1968 House Hearings, supra note 21, at 51 (letter from David E. McGiffert, Acting Secretary, U.S. Army) (supporting legislation with suggested changes). The FPC stated:

[W] do not believe that the uses of any major river, particularly those having significant hydroelectric possibilities, should be himited without a careful study to support such a course of action. The possibility of comprehensive multipurpose development of the $\mathrm{Na}$ tion's water and related land resources must receive the most careful deliberation.

Id. at 174 (FPC Report on H.R. 8416). Similarly, the Acting Secretary of the Army stated:

[T] he Nation can well afford to forego [sic] the development of streams of unusual natnral beauty. ... [T] The report and plan for each proposed wild river should present .... the economic values that would result from its development, so that before the Congress makes a decision it will know what the Nation would be giving up in the form of material wealth in order to preserve the intangible benefits of an unspoiled natural area.

Id. at 50-51 (letter from Acting Secretary McGiffert).

28. Pub. L. No. 90-542, 82 Stat. 906 (1968) (codified as amended at 16 U.S.C. $\$ \S 1271-1287$ (1982 \& Supp. IV 1986)).

29. Id. $\S 1(\mathrm{~b}), 82$ Stat. at 906 (codified at 16 U.S.C. $\S 1271(\mathrm{~b})$ (1982)). For a discussion of the legislative and political activities leading to the WSRA's enactment, see Tarlock \& Tippy, supra note 1 , at $710-12$.

30. WSRA, Pub. L. No. $90-542, \S 1$ (b), 82 Stat. at 906 (qualifying rivers and segments must have "outstandingly remarkable" "scenic, recreational, geologic, fish and wildlife, historic, cultural, or other similar values"). The accompanying House report offered several examples of "outstand- 
cient information to determine immediately which rivers met the criteria. As a response to this lack of information, Congress created two categories of rivers: so-called "instant rivers," 31 which are immediately identifiable as "outstandingly reinarkable," and study rivers, which, though not immediately identifiable as "outstandingly remarkable," are still "worthy of consideration for inclusion in a National Scenic Rivers System" and entitled to essentially the same protection as "instant rivers" pending the outcome of studies'to determine if they meet the "outstandingly remarkable" criteria. ${ }^{32}$ Realizing that even this approach might be too restrictive, Congress provided for additional ways to include rivers in the system: by Act of Congress ${ }^{33}$ and by designation of appropriate stateadministered rivers. ${ }^{34}$

Congress sought to ensure full consideration of both the preservation and developinent values of each proposed wild and scenic river before permanently including it in the system. The WSRA thus requires agencies to prepare a report showing "the characteristics which make the area a worthy addition to the system; the current status of landownership and use in the area; the reasonably foreseeable potential uses of the land and water which would be enhanced, foreclosed, or curtailed if the area were included." 35 This report must then circulate among the relevant federal agencies (Interior, Agriculture, Army, and FERC) for their comments. ${ }^{36}$ The Act also requires the agencies to consult with states unless

ingly remarkable" qualities. Regarding Idaho's Clearwater River, the report found: "All of the segments proposed for scenic river status are fast-flowing with alternating stretches of riffles and pools. Most sections can be travelled by canoe or rubber boat. . . The river's canyons are steepwalled, with numerous cliffs and rock outcrops ...." H.R. REP. No. 1623, 90th Cong., 2d Sess. 4, reprinted in 1968 U.S. CODE CONG. \& ADMIN. NEws 3801, 3804. And regarding the St. Croix River in Minnesota and Wisconsin, the report noted: "Water quality in the river is excellent. Trout, muskellunge, and sturgeon, as well as channel catfish, walleyed pike, and white bass provide a diversity of fishing opportunity." Id. at 6, reprinted in 1968 U.S. CODE CONG. \& ADMIN. NEwS at 3806. The report also emphasized the forest and wildlife qualities of Wisconsin's Wolf River: "Forests bordering the stream are primarily mixed northern hardwoods with occasional pine. These forests support a diversity of game animals, including whitetailed decr and bear. Otter, beaver, unuskrat and mink are common near the river." Id., reprinted in 1968 U.S. CODE CONG. \& ADMIN. NEwS at 3807.

31. H.R. Rep. No. 1623, 90th Cong., 2d Sess. 4, reprinted in 1968 U.S. CODE CONG. \& ADMIN. NEWS at 3805 .

32. See id. at 7-8, reprinted in 1968 U.S. CODE CONG. \& ADMIN. NEwS at 3808.

33. WSRA, Pub. L. No. 90-542, §2(a)(i), 82 Stat. at 906 (codified as amended at 16 U.S.C. $\S 1273(a)(i)(1982))$.

34. Id. $\S 2$ (a)(ii), 82 Stat. at $906-07$ (codifled as amended at 16 U.S.C. $\S 1273$ (a)(ii) (1982)). State-administered rivers can become part of the systein only if designated by a state legislature and accepted by the Secretary of the Interior on application by the Governor of the designating state. Furthermore, these rivers must be administered by the states without expense to the federal government. Id.

35. Id. § 4(a), 82 Stat. at 909 (codified as amended at 16 U.S.C. $\S 1275($ a) (1982)).

36. Id. $\S 4(\mathrm{~b}), 82$ Stat. at 909 (codified as annended at 16 U.S.C. $\S 1275(\mathrm{~b})(1982)$ ). 
all lands that would be affected by inclusion of a river are federally owned. ${ }^{37}$ If a state recommends a river for inclusion under WSRA section 2(a)(ii), the Act requires the Secretary of the Interior to sohcit comments froin all affected federal agencies and to "evaluate and give due weight to any recommendations or comments which the said officials furnish him." 38

By requiring such extensive study and comment before allowing a river to be included within the system, Congress sought to ensure that each designation of a river would best serve the nation. These procedures show that Congress intended that the macro balancing of preservation and developinent values occur at this initial stage. When it designates a river for inclusion, Congress has already set the balance in favor of preservation.

2. Management and Protection of the Wild and Scenic Rivers-The Micro Balance. Congress enacted measures to ensure the preservation of rivers in substantially the same condition as when designated. ${ }^{39}$ A number of these measures restricted the jurisdiction and discretion of administrative agencies when dealing with wild and scenic rivers. Most in1portant were the provisions in WSRA section 7 restricting water resources projects:

(a) The Federal Power Commission shall not license the construction of any dam, water conduit, reservoir, powerlouse, transmission line, or other project works under the Federal Power Act (41 Stat. 1063), as amended (16 U.S.C. 791a et seq.), on or directly affecting any river which is designated in section 3 of this Act as a component of the national wild and scenic rivers system or which is hereafter designated for inclusion in that system, and no department or agency of the United States shall assist by loan, grant, hicense, or otherwise in the construction of any water resources project that would have a direct and adverse effect on the values for which such river was established,

\section{Id.}

38. Id. $\S 4(c), 82$ Stat. at 910 (codified at 16 U.S.C. $\S 1275(c)$ (1982)).

39. These measures included acquiring lands and easements, withdrawing lands from public entry and sale, and patenting new mineral claims. See id. $\S \S 8-10,82$ Stat. at 915-16 (codified as amended at 16 U.S.C. $\S \S 1279-1281$ (1982 \& Supp. IV 1986)) (withdrawing lands from public entry and granting administering Secretary authority to regulate surface and mining activities). The Act grants substantially the same protection to study rivers during the study and consideration periods. See id. $\S \S 8-9,82$ Stat. at 917 (codified as amended at 16 U.S.C. $\S \S 1279-1280$ (1982 \& Supp. IV 1986)) (same protections as for included rivers but no authority to regulate surface activities); see also H.R. Rep. No. 1623, 90th Cong., 2d Sess. 8, reprinted in 1968 U.S. Code Cong. \& ADMIN. News 3801,3809 (The bill "gives the rivers in the study category substantially the same protection ... as it does the rivers which are immediately included ... but this protection is limited to the 5 years following" enactment, plus some additional time for congressional or secretarial consideration,). 
as determined by the Secretary charged with its administration..$^{40}$

In response to conservationists' complaints about agencies' prodevelopment actions, ${ }^{41}$ Congress prohibited agencies froni recoinmending developments that "would have a direct and adverse effect on the values for which [a] river was estabhished" without notifying both Congress and the administering Secretary "in what respect construction of [a] project would be in conflict with the purposes of this Act and would affect the component and the values to be protected by it under this Act."42

Congress was not, however, insensitive to developers' claims that a broad readimg of the WSRA could foreclose developnient of entire river basins. ${ }^{43}$ To clarify its intent, Congress included the following provision:

Nothing contained in the [first sentence of WSRA section 7(a)], however, shall preclude licensing of, or assistance to, developinents below or above a wild, scenic or recreational river area or on any stream tributary thereto which will not invade tlie area or unreasonably diminish tlie scenic, recreational, and fish and wildlife values present in the area on the date of approval of this Act. ${ }^{44}$

40. WSRA, Pub. L. No. $90-542, \S 7$ (a), 82 Stat. at 913 (codified as amended at 16 U.S.C. § 1278(a) (Supp. IV 1986)).

41. For example, Paul M. Tilden, Assistant to the President of the National Parks Association, stated: "The most important thought, therefore, is to protect the wild rivers against the Federal Power Commission, the Army Engineers, the Bureau of Outdoor Recreation, the Tennessee Valley Authority, and other big-dam agencies." 1967 Senate Hearings, supra note 14, at 173 . He then provided an instructive example of agency conduct favoring water resources development:

The American public is well acquainted by now with the promotional activities of [the bigdam] agencies; the process begins with surveys and with the promotion of local interest; the responsible committees of Congress soon find themselves confronted with artificially mobilized political and economic pressures; the agencies customarily refuse to pass their projects through any effective review by the Executive Office of the President.

Id. at 222.

42. WSRA, Pub. L. No. 90-542, § 7(a), 82 Stat. at 913-14; see also id. § 7(b), 82 Stat. at 914 (codified as amended at 16 U.S.C. $\S 1278(b)$ (1982 \& Supp. IV 1986)) (prohibiting construction for at least three years on any potential additions to the wild and scenic rivers system).

43. See supra notes 25-27 and aceompanying text.

44. WSRA, Pub. L. No. 90-542, § 7(a), 82 Stat. at 913. Congress's use of "invade the area" suggests that WSRA section 7 applies only to activities that take place within the boundaries of a wild and scenic river area, except to the extent that the "invade the area or unreasonably diminish the . . . values" clause of the second sentence modifies that limitation.

Defining the boundaries of the wild and scenic river area is thus crucial. The WSRA requires that the administering Secretary of each designated river establish detailed boundaries for the river. These boundaries, which cannot encompass more than an average of 320 acres per river mile, become effective 90 days after the administering Secretary forwards them to the President of the Senate and the Speaker of the House. Id. § 3(b), 82 Stat. at 908 (codified as amended at 16 U.S.C. $§ 1274(\mathrm{~b})$ (Supp. IV 1986)).

Congress defined study river boundaries only indirectly by withdrawing "from entry, sale, or other disposition under the public land laws of the United States" all public lands within one-quarter mile of a study river's bank. Id. $\S 8(\mathrm{~b}), 82$ Stat. at 915 (codified as amended at 16 U.S.C. $\S 1279$ (b) (1982)). Congress was silent about study river boundaries over private lands. 
Finally, Congress provided guidance on the effect of a river's protected status. WSRA section 2(b) required that all rivers

be classified, designated, and administered as [one of] the following:

(1) Wild river areas-Those rivers or sections of rivers that are free of impoundments and generally maccessible except by trail, with watersheds or shorelines essentially primitive and waters unpolluted. These represent vestiges of primitive America.

(2) Scenic river areas-Those rivers or sections of rivers that are free of impoundments, witl shorelines or watersheds still largely primitive and shorelines largely undeveloped, but accessible in places by roads.

(3) Recreational river areas-Those rivers or sections of rivers that are readily accessible by road or railroad, that may have some development along their shorelines, and that may liave undergone some impoundment or diversion in the past. ${ }^{45}$

As the House report explained, this scheme guided the administering Secretaries' deterininations of permissible levels of development. The report, however, also cautioned that "development should in all cases be kept on the inodest side." 46

\section{Subsequent Developments.}

1. WSRA Amendments. Despite frequent amendments to the WSRA, ${ }^{47}$ the contours of the wild and scenic rivers concept have remained essentially unchanged. ${ }^{48}$ When its goals of river preservation and balanced developnient have been threatened, however, Congress has acted decisively. Two exaniples are nistructive.

45. Id. § 2(b), 82 Stat. at 907 (codified at 16 U.S.C. $§ 1273(b)$ (1982)).

46. H.R. Rep. No. 1623, 90th Cong., 2d Sess. 10, reprinted in 1968 U.S. CODE CONG. \& ADMIN. NEWS 3801, 3811; see infra notes 136-37 and accompanying text (discussing river classification as guide to agency discretion).

47. There were 26 annendments as of June 1988. See, e.g., U.S.C.A. index (West 1988) (popular names table).

48. This Note discusses all significant developments. Most amendments have merely added additional rivers to the protected and study categories. The amendments that have addressed the Act's substantive provisions have primarily fine-tuned the administrative procedures. For example, the Act of May 10, 1974, Pub. L. No. 93-279, sec. (1)(b)(1), \& 4(a), 88 Stat. 122, 122 (1974) (codified as amended at 16 U.S.C. $\$ 1275$ (a) (1982)), granted priority to those rivers with "the greatest likelihood of developments which, if undertaken, would render the rivers unsuitable for inclusion." The amendment also extended the protected period for designated study rivers from five to ten years and added a provision granting protection "for a three complete fiscal year period following any Act of Congress designating any river for potential addition." Id. sec. (1)(b)(3), § 7(b)(i), 88 Stat. at 123 (codified as amended at 16 U.S.C. § 1278(b) (1982 \& Supp. IV 1986)) (amending WSRA § 7(b)(i)). A 1975 amendment added to the priority group those rivers "which possess the greatest proportion of private lands." Act of Jan. 3, 1975, Pub. L. No. 93-621, sec. (1)(d)(2), § 4(a)(i), (ii), 88 Stat. 2094, 2096 (codified at 16 U.S.C. § 1275(a) (1982)) (amending WSRA § 4(a)). 
First, in an Act of September 11, 1976,49 Congress directly intervened in a development dispute. The FPC had issued a license to dam the New River in North Carolina. ${ }^{50}$ But the state had included the river in its Natural and Scenic River system ${ }^{51}$ and recommended it for inclusion in the national system under WSRA section 2(a)(ii). ${ }^{52}$ On appeal, the United States Court of Appeals for the District of Columbia Circuit sustained the Commission's hicense. ${ }^{53}$ Congress, however, amended the WSRA, effectively revoking the hicense ${ }^{54}$ and overruling both the court and the FPC.

Second, in an Act of October 30, 1986, ${ }^{55}$ Congress adopted a uniform system for defining study river boundaries. Such boundaries are critical under the WSRA, because the Act provides stricter protection agamst developments inside river boundaries than outside. ${ }^{56}$ In the October act, Congress defined study river boundaries as broadly as possible under the WSRA. ${ }^{57}$ Furthermore, because agencies often failed to finish studies by statutory deadlines, Congress extended protection of study rivers "durmg such interin period froin the date a report is due and the time a report is actually subimitted to the Congress." 58

Aside from these limited changes, theniselves consistent with the wild and scenic rivers concept, the WSRA has reniamed essentially untouched by exphicit ainendinents.

2. Changes in Federal Energy Policy. In its most significant expansion of WSRA protections, Congress has extended federal protection to state wild and scenic river systenis through changes in the interlocking complex of statutes that govern federal energy policy.

49. Pub. L. No. 94-407, 90 Stat. 1238 (codified as amended at 16 U.S.C. $\$ \S 1273,1278$ (1982 \& Supp. IV 1986)).

50. Appalachian Power Co., Project No. 2317, 51 F.P.C. 1906 (1974).

51. Act of Feb. 21, 1974, ch. 879, 1973 N.C. Sess. Laws 37 (codified as amended at N.C. GEN. STAT. § 113A-35.1 (1983)).

52. North Carolina v. FPC, 533 F.2d 702 (D.C. Cir.), vacated, 429 U.S. 891 (1976).

53. Id. at 709-10.

54. Act of Sept. 11, 1976, Pub. L. No. 94-407, sec. 1(2), § 7(a), 90 Stat. at 1238 (codified as amended at 16 U.S.C. $\S 1278$ (a) (Supp. IV 1986)) ("Any license heretofore or hereafter issued by the Federal Power Commission affecting the New River of North Carolina shall continue to be effective only for that portion of the river which is not included in the National Wild and Scenic Rivers System ...."?).

55. Pub. L. No. $99-590,100$ Stat. 3330 (codified in scattered sections of 16 U.S.C.).

56. See WSRA § 7(a), (b), 16 U.S.C. $\S 1278(a)$, (b) (1982 \& Supp. IV 1986).

57. The new provision defined the protected zone, for both designated rivers before final boundary publication and study rivers, as "that area measured within one-quarter mile from the ordinary high water mark on each side of the river." Act of Oct. 30, 1986, Pub. L. No. 99-590, § 502, 100 Stat. at 3335 (codified at 16 U.S.C. $\$ 1275$ (d) (Supp. IV 1986)) (amending WSRA § 4(d)).

58. Id. $\S 505(\mathrm{~b}), 100$ Stat. at 3336 (codified at 16 U.S.C. $\S 1278(\mathrm{~b})(\mathrm{ii})$ (Supp. IV 1986)) (amending WSRA $\S 7(b))$. 
The process began in 1980, when Congress enacted the Energy Security Act (ESA). 59 ESA section 408 allowed FERC to "grant an exemption in whole or in part from the requirements (including the licensing requirements) of part I of the Federal Power Act to small hydroelectric power projects having a proposed installed capacity of 5,000 kilowatts or less," 60 but still required exeinpted projects to comply with environmental regulations. ${ }^{61}$

In Swanson Mining Corp., Project No. 5677-000, 62 FERC examined the WSRA's applicability to an ESA exemption. ${ }^{63}$ Citing only the language of WSRA section 7(a), FERC claimed that it was "without authority to approve the development proposed by this exemption application"64 and vacated Swanson's exeinption. ${ }^{65}$ As FERC explained in Lawrence J. McMurtrey, Project No. 6307-002:

The Wild and Scenic Rivers Act prohibits this Commission from hcensing or otherwise "assisting" in the construction of hydropower facilities that would directly and adversely affect the values for which a river is protected. Issuing an exemption from hicensing for a project that would have such an effect is therefore prohibited. ${ }^{66}$

Swanson appealed the FERC decision, and in Swanson Mining Corp. v. FERC the D.C. Circuit upheld the Commission's action. ${ }^{67}$ The court found that "[t]he grant of an exemption under the Energy Security Act is

59. Pub. L. No. 96-294, 94 Stat. 611 (1980) (codified as amended in scattered sections of 7 U.S.C., 12 U.S.C., 15 U.S.C., 16 U.S.C., 30 U.S.C., 42 U.S.C., and 50 U.S.C.) [cited hereinafter as ESA].

60. Id. $\S 408(b), 94$ Stat. at 718 (codified at 16 U.S.C. $\S 2705$ (d) (1982)). Part I of the FPA contains basic procedures and requirements for any hydroelectric project license application. See FPA $\S \S 1-30,320,16$ U.S.C. $\$ \S 791 a-823 a$ (1982 \& Supp. IV 1986).

61. ESA, Pub. L. No. 96-294, § 408(b), 94 Stat. at 718; see also H.R. Conf. REP. No. 1104, 96th Cong., 2d Sess. 276, reprinted in 1980 U.S. CODE CONG. \& ADMIN. NEws 2077, 2172 ("In granting an exemption from license requirements, [FERC] will reach its determination only after full compliance with the requirements of the Fish and Wildlife Coordination Act, the National Environmental Policy Act, and any other provision of Federal law.").

62. 22 F.E.R.C. If 61,184 , at 61,318 (1983).

63. The exemption had been granted by operation of law on May 11, 1982, pursuant to Exemption from all or Part [sic] of Part I of the Federal Power Act of Small Hydroelectric Power Projects with an Installed Capacity of 5 Megawatts or Less, FERC Order No. 106, 45 Fed. Reg. 76,115 (1980). Swanson Mining Corp., Project No. 5677-000, 19 F.E.R.C. If 62,274, at 63,485 (1982), vacated, 22 F.E.R.C. at $61,319$.

64. Swanson Mining Corp., Project No. 5677-000, 22 F.E.R.C. at 61,319.

65. Id. at 61,320 .

66. Lawrence J. McMurtrey, Project No. 6307-002, 23 F.E.R.C. If 61,246, at 61,533 (1983) (citation omitted). A group of Indian tribes appealed an order granting McMurtrey an exemption from licensing. The tribes argued that the exemption was improper "because some of the project facilities would be constructed in an area protected from development under the Wild and Scenic Rivers Act." Id. (footnote omitted). FERC agreed and rescinded the order granting the exemption. Id.

67. 790 F.2d 96, 106 (D.C. Cir. 1986). 
the factual equivalent of the grant of a license through a simplified and expedited procedure."68 The court then concluded that "the Wild and Scenic Rivers Act's limitations on FERC's licensing authority also apply to its autlority to grant exemptions." 69

Congress resolved the exenption issue by enacting the Electric Consumers Protection Act of 1986 (ECPA), ${ }^{70}$ which imposed an additional requirement on ESA exemptions:

At the time the application for a hicense or exemption for the project is accepted by the Commission [the Commission must find that] such project is not located on either of the following:

(A) Any segment of a natural watercourse which is included in (or designated for potential inclusion in) a State or national wild and scenic river system.

(B) Any segment of a natural watercourse which the State has determined, in accordance with applicable State law, to possess unique natural, recreational, cultural, or scemic attributes which would be adversely affected by hydroelectric development. ${ }^{71}$

The ECPA dramatically expanded the scope of wild and scenic rivers coverage by protecting state wild and scenic rivers systems from hydropower-license-exenipt developnient. The WSRA had left state rivers unprotected unless they were included in the national wild and scemic rivers system under WSRA section 2(a)(ii). ${ }^{72}$

\section{Conflict over Determination Authority-A Resolution}

While regnlations governing implententation of the WSRA's sub-

68. Id. at $98 \mathrm{n}$.1. In support of its holding that the exemption fell nnder the WSRA, the court cited 16 U.S.C. $\$ 2705$ (d) (1982), which states: "Except as specifically provided in this subsection, the granting of an exemption to a project under this subsection shall in no case have the effect of waiving or limiting the application (to such project) of the second senteuce of subsection (b) of this section." The second sentence of subsection (b) reads: "Nothing in this subsection exempts any such project from any requirement applicable to any such project under . . . any other provision of Federal law." Id. § 2705(b).

69. Swanson Mining, 790 F.2d at 98 n.1. The court's rationale differed from FERC's in at lcast one important respect. FERC based its decision to vacate on WSRA section 7's general prohibition against any "department or agency of the United States" aiding a water resources project, rather than on section 7's ban on licenses. Swanson Mining, Project No. 5677-000, 22 F.E.R.C. at 61,319 (citing WSRA $\S 7($ a), 16 U.S.C. $\$ 1278$ (a) (Supp. IV 1986)). The D.C. Circuit, in contrast, analogized an exemption to a license and applied section 7(a)'s prohibition on licenses. 790 F.2d at 102.

70. Pub. L. No. $99-495,100$ Stat. 1243 (codified in scattered sections of 16 U.S.C.) [cited hereinafter as ECPA]. 1986)).

71. Id. sec. $8(a), \S 210(j)(2), 100$ Stat. at 1249 (codified at 16 U.S.C. $\S 824 a-3(j)(2)$ (Supp. IV

72. North Carolina v. FPC, 533 F.2d 702, 708-09 (D.C. Cir.) (WSRA does not protect unlisted rivers not formally accepted by Secretary of Interior for inclusion in national wild and scenic rivers system), vacated, 429 U.S. 891 (1976). 
stantive provisions have been slow in coming, ${ }^{73}$ the Departments of the Interior and Agriculture have fought vigorously with FERC, the principal authorizing agency, for jurisdiction to determine whether planned developments violate the WSRA. The derivation of the wild and scernc rivers program from multiple statutes aggravates the conflict. ${ }^{74}$ In recent years, the Departinents of the Interior and Agriculture have assumed an increasing proportion of determination authority (except under the ECPA, which expressly gives FERC the ministerial task of determining whether a proposed development falls within a state or national wild and scenic river area ${ }^{75}$ ). The following sections discuss this salutary trend against the background of the agencies' continuing struggle over determ:nation authority.

\section{A. Federally Administered Rivers.}

The proper determining agency under the first sentence of WSRA subsection 7(a) and the first sentence of WSRA subsection 7(b) ${ }^{76}$ is no longer seriously contested. Despite some initial opposition,77 FERC agreed in the landmark case of China Flat Co., Project No. 7258-0001 ${ }^{78}$ that

[t] he statutory scheme of the WSRA, which gives the Secretary of the Interior or the Secretary of Agriculture the responsibility for administering, managing, and protecting these rivers, and the legislative history of the WSRA indicate that the responsibility for determining whether a proposed project is consistent with the WSRA belongs to

73. The Departments of the Interior and Agriculture did not issue their Final Revised Guidelines for Eligibility, Classification and Manageinent of River Areas, 47 Fed. Reg. 39,454 (1982), until 1982 - fourteen years after Congress passed the WSRA. Similarly, the Department of Agriculture did not issue its regulations governing water resources projects until 1984. See Wild and Scenic Rivers, 36 C.F.R. $\S 297$ (1988). The Department of the Interior has yet to promulgate its regulations.

74. Both the WSRA and the ECPA protect wild and scenic rivers. See supra notes 39-58, 7072 , and accompanying text.

75. H.R. REP. No. 507, 99th Cong., 2d Sess. 44, reprinted in 1986 U.S. CoDE CoNG. \& ADMIN. News 2496, 2531 ("[T]he Commission must determine that the project is not located on ... a State or national wild and scenic system ....").

76. WSRA § 7(a), (b), 16 U.S.C. § 1278(a), (b) (1982 \& Supp. IV 1986).

77. Resistance to Interior and Agriculture's claims actually began with the FPC, FERC's predecessor. See, e.g., City of Seattle, Dep't of Lighting, Project No. 553, 59 F.P.C. 196, 206 (1977) (FPC, finding that project did not "appreciably affect" protected portion of river, granted license); Great Northern Nekoosa Corp., Project No. 2458, 54 F.P.C. 1097, 1098-99 (1975) (approving project despite Interior's request for stay to determine inpact on wild and scenic river). FERC initially continued the FPC's position. See, e.g., City of Seattle, Dep't of Lighting, Project No. 533, 4 F.E.R.C. \ 61,114, at 61,245 (1978) ("There is no provision in the statute that the FPC was required to seek such a determination [from the Department of the Interior], and therefore there is no bar in the Wild \& Scenic Rivers Act to the Commission granting a license . . . ").

78. 27 F.E.R.C. I 61,024 (1984). 
the Secretary administering the river. ${ }^{79}$

The consensus breaks down, however, at the second sentence in each subsection. ${ }^{80}$ FERC has asserted that it has exclusive authority to determine whether a proposed project above or below a wild and scenic river violates the WSRA: "The Commission is also precluded from licensing any project work above or below a wild or scenic river that would, in the Commission's judgment, 'invade' or 'unreasonably diminish the ... values present." "81 FERC argues that it has no obhigation to consult the administermg Secretary because " $[t]$ here is no provision in the [WSRA] that the FPC [FERC's predecessor] was required to seek such a determination." 82

The Departments of Agriculture, ${ }^{83}$ and presumably Interior, ${ }^{84}$ dispute FERC's contention. Both the context of the statutory language ${ }^{85}$

79. Id. at 61,041 . The WSRA does not define which Secretary is charged with administration. WSRA section 3 lists the included rivers and designates the Secretary responsible for their administration. See WSRA § 3(a), 16 U.S.C. § 1274(a) (1982 \& Supp. IV 1986). With regard to study rivers, WSRA section 4(a) states: "The Secretary of the Interior or, where national forest lands are involved, the Secretary of Agriculture or, in appropriate cases, the two Secretaries jointly shall study ... the suitability . . of rivers . . . " Id. $\S 4(a), 16$ U.S.C. $\S 1275(a)$ (1982).

80. The second sentence of subsection 7(a) reads: "Nothing contained in the foregoing sentence, however, shall preclude licensing of, or assistance to, developments below or above a wild, scenic or recreational river area or on any stream tributary thereto which will not invade the area or unrcasonably dimimish the scenic, recreational, and fish and wildlife values present in the area on the date of approval of this Act." WSRA § 7(a), 16 U.S.C. § 1278(a) (Supp. IV 1986). The language in WSRA section 7(b) is substantially the same, except that it refers to "a potential wild, scenic or recreational river area." Id. § 7(b), 16 U.S.C. § 1278(b) (1982 \& Supp. IV 1986).

81. Modesto Irrigation Dist., Project No. 3262, 17 F.E.R.C. $\ 61,114$, at 61,281 (1981) (emphasis added). The case concerned a preliminary permit, but the language is indicative of FERC's position generally.

82. City of Seattle, Dep't of Lighting, Project No. 533, 4 F.E.R.C. $\{61,114$, at 61,245 (1978) (FERC argues that "there is no bar in the Wild \& Scenic Rivers Act to the Commission granting a hicense" in the absence of a statutory provision requiring secretarial determination).

83. See Wild and Scenic Rivers, 36 C.F.R. $\$ 297.5(a)(2)-(3)$ (1988) (Agriculture requires secretarial determination for both designated and study rivers under either "invade" or "unreasonably diminish" language).

84. Although Interior has not publicly stated its position, past Department practice indicates general agreement with Agriculture on wild and scenic rivers matters. See, e.g., National Wild and Scemc Rivers System; Final Revised Guidehnes for Eligibility, Classification, and Management of River Areas, 47 Fed. Reg. 39,454 (1982) (Interior and Agriculture joint regulations).

85. The "invade or unreasonably diminish" standard appears in the second sentences of WSRA subsections 7(a) and (b). WSRA $§ 7(a)$, (b), 16 U.S.C. $\S 1278(a)$, (b). The 1968 conference committee added this language. See H.R. Conf. REP. No. 1917, 90th Cong., 2d Sess. 16-17 (1968); see also supra notes $43-44,80-82$, and accompanying text. Prior to that addition, WSRA section 7 clearly required seeretarial determinations. The first and third sentences of each subsection refer to the "Secretary charged with [the affected river's] administration" (or "its study and approval") and "Secretary of the Interior or the Secretary of Agriculture, as the case inay be" (or "Secretary of the Interior, and where national forest lands are involved, the Secretary of Agriculture"). WSRA § 7(a), (b), 16 U.S.C. $\S 1278(a)$, (b). WSRA subsection 7(c) makes a similar reference to the Secretaries. WSRA $\S 7(\mathrm{c}), 16$ U.S.C. $\S 1278(\mathrm{c})(1982)$. 
and the legislative history support the Departments' position. In his 1968 section-by-section analysis of the WSRA, Senator Nelson (D-Wis.) concluded that " $[t]$ he section contemplates that . . upstream and downstream developments . . . will be subject to review and comment by the appropriate Secretary pursuant to this section." 86 The D.C. Circuit agrees. ${ }^{87}$

The Departments' position has practical justification as well. First, as administrators of the wild and scenic rivers program, the Departnents are familiar with the values present $\mathrm{n} 1$ each river area. This knowledge enables them to make informed decisons about a proposed project's potential impact. The authorizing agencies, im contrast, have little exposure to the values of individual wild and scemic rivers and lack the Departments' site-specific expertise. Second, the Departments, if given full determination authority, will eventually develop a uniform approach to managing wild and scenic rivers that will lead to consistent treatnient of all developments in the systen. Fimally, entrusting impact evaluation to the authorizing agencies would create a multiplicity of forms and procedures obstructing the approval process for proposed developments. ${ }^{88}$ Practical considerations of expertise and administrative convenience, therefore, favor vesting determination authority in the Departnent of the Interior and Department of Agriculture.

\section{B. State-Administered Rivers.}

Both the states and the administerimg Secretaries claim primary determination authority for state-administered rivers. Their dispute stems from an mconsistency in the WSRA. The Secretaries rely on WSRA section 7(a), which refers to the "Secretary charged with administration."89 The states point to WSRA section 2(a)(ii), which says that state rivers "are to be permanently administered . . . by an agency or political subdivision of the State,"90 thus implying no secretarial involvement.

86. 114 CoNG. Rec. 28,313 (1968) (statement of Sen. Nelson).

87. See Swinomish Tribal Community v. FERC, 627 F.2d 499, 507-08 (D.C. Cir. 1980) ("The Secretary of the Interior or, where national forest lands are involved, the Secretary of Agriculture, are secretaries having jurisdiction to make determinations under the WSRA prior to licensing.").

88. Each authorizing agency would probably require developers to follow its own review procedures. The Departments of the Interior and Agriculture would also intervene to express their concerns. Each developer would thus face not two procedures before administering Secretaries, but as many procedures as there are authorizing agencies, as well as Interior's and Agriculture's imtervention. Such a situation would increase the burden on authorizing agencies, developers, and the Departments of the Interior and Agriculture.

89. WSRA $\S 7(a), 16$ U.S.C. $\S 1278(a)$.

90. Id. §2(a)(ii), 16 U.S.C. §1273(a)(in) (1982). 
Indeed, the states might be the better determining authorities. They inight be able to determine inore accurately when a proposed development would affect their rivers than could a national entity that does not manage the rivers, such as Agriculture or Interior. Moreover, portions of the WSRA's legislative history, ${ }^{91}$ as well as FERC's decision in Swanson Mining Corp., Project No. 5677-000, 92 support the view that the states are the proper determining authority.

That view, however, faces an insuperable difficulty: WSRA section 7(a) calls for determinations by the "Secretary charged with [the affected river's] administration."93 An analogy to WSRA section 7(b), which requires determinations "by the Secretary responsible for [the river's] study or approval," 94 suggests that Interior is the Secretary to which WSRA section 7(a) refers. Indeed, the D.C. Circuit adopted this view in Swanson Mining Corp. v. $F E R C$, noting that Swanson's claim regarding an incorrect determining agency "overlooks the fact that the South Fork is a state-designated coinponent of the national wild and scenic rivers system. The [WSRA] vests the Secretary of the Interior with responsibility for such rivers." 95 Both the legislative history ${ }^{96}$ and Senator Nelson's section-by-section analysis ${ }^{97}$ of the WSRA support the court's conclusion in

91. "Administration of the rivers in the system would be . . by the States or local governmental agencies, exclusively." S. REP. No. 491, 90th Cong., 1st Sess. 4 (1967).

92. 22 F.E.R.C. ๆ 61,184, at 61,318 (1983). "Because the [California] Resources Agency's objection is now based on the specific environmental impacts of this proposed project on a wild and scenic river, we conclude that the Commission is without authority to approve . . . this exemption application." Id. at 61,319 (footnote omitted). Neither Interior nor Agriculture was involved in the Swanson Mining proceedings at the time of this decision.

93. WSRA § 7(a), 16 U.S.C. $\S 1278(a)$.

94. Id. $\S 7(b), 16$ U.S.C. $\$ 1278(b)$. The Secretary of the Interior is responsible for approval of state-recommended rivers. Id. $\$ 2$ (a)(ii), 16 U.S.C. $\$ 1273$ (a)(ii).

95. Swanson Mining Corp. v. FERC, 790 F.2d 96, 103 n.5 (D.C. Cir. 1986). The case was an appeal of FERC's denial of an exemption under the ESA. See supra notes 67-69 and accompanying text. In the interim between FERC's demial of the exemption and the appcal, FERC asked Interior to inake a determination. In its argument before the D.C. Circuit, FERC rehed on that determination rather than one by the California Resources Agency. 790 F.2d at 100, 103-04.

96. The report accompanying the House's variant of the WSRA stated that the House bill "throws around State-named rivers which are included in the National Scenic Rivers System and around the rivers listed in section 5 which are being studied by a State or local agency the same protection against adverse Federal agency action" as it aecords to federally named and studied rivers. H.R. ReP. No. 1623, 90th Cong., 2d Sess. 8, reprinted in 1968 U.S. CODE CoNG. \& ADMIN. NEws 3801, 3808-09. This statement implies that the protection meclianism for federally administered rivers, which requires secretarial determination, also applies to state-administered rivers. Although the Senate report did speak of exclusive administration by the states, see S. REP. No: 491 , 90th Cong., 1st Sess. 4 (1967), the conference committce rejected the Senate's position and adopted the House plan for administration, see H.R. CoNf. REP. No. 1917, 90th Cong., 2d Sess. 15 (1968) ("conference committee substitute adopts the forniat and substance of the House amendment").

97. The analysis reads in part:

The Seeretary administering the designated river is responsible for deternining whether suclı project would directly affect tlie designated river, in the case of an FPC license, and 
Swanson. Furthermore, any considerations of administrative convenience and uniform application of procedure that favor secretarial determination for federal rivers apply to state-admimistered rivers as well..$^{98}$

\section{Standards Governing Water RESources DEVElopment ON WILD AND SCENIC RIVERS}

The WSRA, ECPA, and related legislation establish a complex, but comprehensive, scheme for regulating water resources development within wild and scenic river basins. What remains is to distill from the legislative language a series of coinprehensible standards for determining whether a proposed project is permissible under the wild and scemic rivers scheme. Fortunately, this task is not as difficult as it might appear. Four standards, drawn from the statutory language, capture the nuances of the entire scheme with its carefully chosen approach to federal water policy. These standards will effectively guide and control administrative discretion, advancing Congress's dual goals of river preservation and balanced resource development.

The first two standards, here denominated the "exempted project" and the "on or directly affecting" standards, determine whether Congress intended to categorically exclude a proposed project from wild and scenic river areas. The standards are thus ministerial; they merely require a finding that an appropriate authority has desiguated the river im question as wild, scenic, or recreational. If a proposed project survives these ministerial standards, it is evaluated under one of the second two standards. These standards, here denominated the "direct and adverse effect" and the "invade or unreasonably dimmish" standards, are judgmental; they govern a determining agency's discretion as it decides whether to allow a proposed project. This part will examine each of the four standards in turn.

A hypothetical exainple will help to illustrate the standards' application: A developinent coinpany proposes to build three hydroelectric dams. The company will build Upper Dam two miles above a wild and scenic river's upper boundary; Middle Dam, within the river area, using an existing diversion structure; and Lower Dain, one mile below the river area's lower boundary. The Note will analyze the application of each standard to these hypothetical projects.

whether such project would have a direct and adverse effect on the river, in the case of projects constructed with the assistance of another Federal agency or under such agency's license or permit.

114 CONG. REC. 28,313 (1968) (stateinent of Sen. Nelson).

98. See supra note 88 and accompanying text. 


\section{A. The "Exempted Project" Standard.}

No exemption shall apply to any hydroelectric project utilizing a new dam or diversion if such project is located on any segment of a natural water course designated for inclusion (or potential inclusion) in a state or national wild and scenic river system. ${ }^{99}$

This standard, established by the ECPA, apphies to projects seeking exemption from standard licensing procedures under ESA section 408. In making determinations under this standard, FERC, the determining agency, ${ }^{100}$ should apply the following definitions:

- Hydroelectric project. "Project" encompasses all aspects of a hydroelectric generating system, including the dam or diversion, power transmission lines, water conduits, and otler structures. ${ }^{101}$

- New dam or diversion. The term "new dam or diversion" includes completely new structures, as well as existing structures that require, "for purposes of imstalling any hydroelectric power project, any construction, or enlargement of any impoundment or diversion structure," excepting repairs and reconstruction of adjustable devices such as floodgates. ${ }^{102}$

- Located on. "On" ineans within the delineated boundaries of a state or national wild and scenic (or study) river. ${ }^{103}$

99. The standard is adapted from language found in ECPA, 16 U.S.C. $\S 824 a-3(j)(2)(A)$ (Supp. IV 1986). The standard also applies to substantial equivalents of a wild and scemic river. Id. $\S 824 a$ 3(j)(2)(B).

100. See H.R. REP. No. 507, 99th Cong., 2d Sess, 44, reprinted in 1986 U.S. CodE CoNG. \& ADMIN. News 2496, 2531; 18 C.F.R. $\$ 292.203$ (c)(1)(iii)(A)-(B) (1988).

101. FPA § 3, 16 U.S.C. $\$ 796(11)$ (1982):

"[P]roject" means complete unit of improvement or development, consisting of a power house, all water conduits, all dams and appurtenant works and structures (including navigation structures) whicli are a part of said unit, and all storage, diverting, or forebay reservoirs directly connected therewith, the primary line or lines transmitting power tlierefrom to the point of junction with the distribution system or with the interconnected primary transmission system, all miscellaneous structures used and useful in connection witl said unit or any part thereof, and all water-riglits, rights-of-way, ditches, dams, reservoirs, lands, or interest in lands the use and occupancy of which are necessary or appropriate in the maintenance and operation of such unit ....

102. ECPA, 16 U.S.C. $\$ 824 a-3(k)$ (Supp. IV 1986).

103. "On" usually means "[u]pon; . . . along; along side of; adjacent to; contiguous to." BLACK's LAw DictionaRy 981 (5th ed. 1979). By analogy, in the WSRA, Congress allows developments "below or above" tlie designated (or protected) stretch of the wild and scenic or study river, but prohibits developments "on" or "along side of" it. For convenience, this latter area can be defined as the area within the boundaries of the wild and scenic or study river component. The Department of Agriculture has achieved the same result by defining a "wild and scenic river" as "a river and the adjacent area within the boundaries of a component of the National Wild and Scenic Rivers System pursuant to [WSRA] section 3(a) or 2(a)(ii)." 36 C.F.R. $\$ 297.3(\mathrm{c})$, para. 5 (1988). Agriculture similarly defines "study river" as "a river and the adjacent area within one quarter mile of the banks 
- Included in (or designated for potential inclusion in) a state or national wild and scenic river system. This last requirement protects state equivalents of wild and scemic rivers. ${ }^{104}$ FERC's role in applying this requirement is strictly ministerial; rather than itself evaluating a river, FERC merely reports whether an appropriate authority has designated the river for mclusion in the systein. ${ }^{105}$

One should read the standard as a whole to understand its sweep. Thus, under the broad definition of "project," if any part of a planned project, even a part other than the actual dam or diversion, is located within the boundaries of a wild and scenic river, the project cannot be exeinpted, provided that: (a) the dam or diversion is new and (b) the part of the project located "on" the river did not exist in substantially the same condition at the time the river entered the wild and scenic river system. ${ }^{106}$ If the project falls within these categories, FERC cannot exempt it from normal licensing procedures. ${ }^{107}$ Such a project could still be built, however, if it were hicensed under the procedure estabhished in part I of the Federal Power Act. ${ }^{108}$

In our hypothetical, because Upper and Lower Dams are outside the wild and scenic river area, the "exenupted project" standard would not apply. The Middle Dain, however, as a "project" within the wild and scenic river area, would violate the standard. Middle Dam thus would not be exempt from FPA hicensing requirements unless it qualified as an "existing facility." To qualify as such, the project must accommo-

of the river which is designated for study as a potential addition to the National Wild and Scenic Rivers System pursuant to [WSRA] section 5(a)." Id. \$ 297.3(c), para. 3.

104. ECPA, 16 U.S.C. $\S 824 a-3(j)$ (2)(B) (Supp. IV 1986); see supra text accompanying note 71 (quoting the section).

105. "The Committee does not intend that the Commission will have independent authority to review whether the waterway possesses such [wild and scenic river] attributes." H.R. REP. No. 507, 99th Cong., 2d Sess. 44, reprinted in 1986 U.S. CODE CONG. \& ADMIN. News 2496, 2531.

106. For example, an existing use within a wild and scenic river area would be permissible, because it would not implicate the congressional policy of protecting such rivers from additional degradation. In contrast, a new use within the wild and scenic river area would implieate the congressional policy, because it would cause new degradation. The standard would thus prohibit only the new use.

107. The ECPA also prohibits the granting of an exemption if the project falls within a substantial equivalent of a state or national wild and scenic river area. See ECPA, 16 U.S.C. § 824a-3(j)(2).

108. The ECPA only prohibits FERC from granting exemptions from the licensing requirements of the FPA; it does not forbid construction of the proposed projects themselves. If the proposed project is on a state-protected river, the developer would be free to construct the project under a FERC license, since the WSRA provisions do not apply to state wild and scenic rivers or their equivalents. See supra note 72 and accompanying text. Thus, developments on state-protected rivers would not be barred, although FERC might be less likely to grant a license for a project on or affecting a state-protected river. 
date hydroelectric equipment in a preexisting structure without any construction or enlargement. Since it is unlikely that the developer could build an economically successful hydroelectric project without such modifications, ${ }^{109}$ the FPA's regnlar licensing procedures wonld apply.

\section{B. The "On or Directly Affecting" Standard.}

The Federal Energy Regulatory Commission shall not hicense the construction of any dam, water conduit, reservoir, powerhouse, transmission line, or other project works under the Federal Power Act (41 Stat. 1063), as amended (16 U.S.C. 791a et seq.), on or directly affecting any river which is designated in [WSRA section 3(a) or 5(a)] as a component [or potential component] of the national wild and scemic rivers system or which is hereafter designated for mclusion in that system ....110

This standard, directed exclusively at FERC, was established by WSRA section 7. The Secretary of the Interior, or where national forest lands are involved, the Secretary of Agriculture, must make determinations whetlier a proposed project satisfies the standard.111 In domg so, the appropriate Secretary should apply the following definitions:

- License. This term includes any license, modification, renewal, or exemption of a project, as defined by the FPA. ${ }^{112}$

109. The developer is unlikely to succeed with an existing diversion structure for two reasons. First, it is unlikely that any wild or scenic rivers contain a diversion structure large enough to create the "liead" (i.e., the deptll of turbine intake below water level) necessary for a lydroelectric operation. Indeed, rivers are designated as wild and scenic in part because of the absence of such developments. Second, even if a sniall diversion did exist, the developer probably could not coniplete the project without violating the statutory prohibition on "any construction[] or enlargenient of any impoundment or diversion structure" "for purposes of installing any liydroelectric project." ECPA, 16 U.S.C. $\S 824 \mathrm{a}-3(\mathrm{k})$ (Supp. IV 1986).

110. WSRA § 7(a), (b), 16 U.S.C. $\$ 1278$ (a), (b) (1982 \& Supp. IV 1986) (emphasis added). WSRA section 7(b), which governs study rivers, contains substantially the same language, except that the phrase "which is listed in section 1276(a) of this title" replaces the plirase "which is designated in [WSRA section 3(a)] as a component of the national wild and scenic rivers systen or which is hereafter designated for inclusion in tlat systen.." Compare id. $\S 7(\mathrm{~b}), 16$ U.S.C. $\S 1278(\mathrm{~b})$ with id. $\S 7(\mathrm{a}), 16$ U.S.C. $\S 1278(\mathrm{a})$.

111. See supra notes $76-98$ and acconipanying text.

112. While the standard explicitly refers only to licenses, it should not enable FERC to accomplish indirectly what the standard prohibits directly. Two lines of argunient suggest that FERC must follow the same process for license nodifications and renewals that it follows for initial licenses. First, by analogy to the license exeniptions that the D.C. Circuit prohibited in Swanson Mining Corp. v. FERC, 790 F.2d 96 (D.C. Cir. 1986), FERC should not be able, without obtaining a secretarial determination, to approve a license modification or renewal that would violate any of the wild and scenic rivers standards. Second, even if the standard does not prolibit such approvals, Lawrence J. McMurtrey, Project No. 6307-002, 23 F.E.R.C. ๆ 61,246, at 61,533 (1983), suggests that the "direct and adverse effect" standard will. As the Comnission held in McMurtrey, the WSRA prolibits FERC from "otherwise 'assisting' in the construction of hydropower facilities that would directly and adversely affect" the river. Id.; see infra notes $116-41$ and acconipanying text 
- Project works. The term "project works" refers to any "physical structures of a project."113 A "project" is a "complete umt of improvement or development" under the FPA. ${ }^{114}$

- On or directly affecting. This requirement limits the standard's application to project works within the delineated boundaries of a wild and scenic or study river. The standard does not affect activities outside the dehineated boundaries. ${ }^{115}$

- River designated for inclusion. This clause refers to rivers designated pursuant to WSRA section 3(a), 5(a), or 2(a)(ii). It also allows Congress to add additional rivers to the system without amending WSRA section 3(a).

Reading this standard as a whole, if the appropriate Secretary determines that any part of a proposed project falls within the boundaries of a wild and scenic (or study) river area, the project is prohibited and FERC may not issue a license, modification, or amendment concerning the project.

Under our hypothetical, Middle Dam could not be built because it is a "project" within a wild and scenic river area. Neither of the ministerial standards, however, would prohibit construction of Upper Dam or Lower Dam.

\section{The "Direct and Adverse Effect" Standard.}

[N]o department or agency of the United States shall assist by loan, grant, license, or otherwise in the construction of any water resources project that would have a direct and adverse effect on the values for which such river [designated pursuant to WSRA section 3(a), 5(a), or 2(a)(ii)] was established, as determined by the Secretary charged with its administration. ${ }^{116}$

This standard, too, was established by WSRA section 7. It entrusts determinations of a project's "direct and adverse effect" to the Secretary of the Interior or, where national forest lands are involved, to the Secre-

(discussing the "direct and adverse effect" standard). Approving a license modification or renewal request surely falls into this "otherwise assisting" category.

113. FPA § 3, para. 12, 16 U.S.C. $\S 796(12)$ (1982).

114. Id. $\S 3$, para. 11, 16 U.S.C. $\S 796(11)$ (1982); see supra note 101 (text of statutory definition).

115. See supra note 103 and accompanying text.

116. WSRA $\S 7(a),(b), 16$ U.S.C. $§ 1278(a)$, (b). Substantially similar language governs study rivers, except that "was established" is replaced in WSRA section 7(b) by "might be designated," and "Secretary charged with its administration" is replaced in section 7(b) by "Secretary responsible for its study or approval." Compare id. § 7(a), 16 U.S.C. $\S 1278($ a) with id. $\S 7(\mathrm{~b}), 16$ U.S.C. $\S 1278$ (b). 
tary of Agriculture. ${ }^{117}$ In making such a determination, the Secretary should apply the following definitions:

- No department or agency of the United States. As this requirement indicates, the standard addresses only actions by instrumentahities of the federal government. It does not affect actions by state and local governments or private parties.

- Assist in the construction. This language is broad, but room for disagreement over its scope exists at the margins. ${ }^{18}$ The phrase appears to forbid any act that could facilitate construction of a water resources project that would have a direct and adverse effect on a protected river. Even the granting of an access easement, for example, could be prohibited.

- Construction. "Construction" is a crucial concept. A narrow reading of the term would limit the protection given affected rivers, whereas a broad reading would greatly increase that protection.

In its regulations, the Department of Agriculture has adopted a broad reading of the term. The regulations define "construction" as "any action carried on with Federal assistance," 119 and

117. See supra notes $77-98$ and accompanying text.

118. An excellent example is the ongoing controversy between FERC and the Departinents of the Interior and Agriculture over whether the prohibition on licensing includes a "preliminary permit." FERC, like the FPC before it, insists that a preliminary permit does not assist construction. See, e.g., Modesto Irrigation Dist., Project No. 3262, 17 F.E.R.C. ๆ 61,144, at 61,281 (1981) (WSRA "does not prohibit issuance of a preliminary permit"); City of Delta, Project No. 2792, 4 F.E.R.C. ๆ 61,102, at 61,212 (1978) ("preliminary permit does not 'assist ... in the construction' of a potential hydrcelectric project"). As FERC noted in City of Delta, a preliminary permit is not a necessary precursor to a license, not all preliminary permits lead to licenses, and the purpose of the permit at issue was merely to maintain priority of license. FERC therefore concluded in City of Delta that the WSRA "neither prohibits issuance of this preliminary permit nor requires that any studies to be conducted in compliance with this permit be approved in advance by the Secretary of the Interior." Id.

The Departments of Agriculture and the Interior disagree with FERC's interpretation of the preliminary permit. In City of Delta, Interior questioned FERC's authority to issue a preliminary permit without Interior's approval, which Interior thought was required under WSRA section 7(b). Id. The Department of Agriculture has challenged FERC's interpretation by defining the phrase "federal assistance" in Agriculture's regulations under the WSRA as "a license, permit, preliminary permit, or other authorization granted by the Federal Energy Regulatory Commission pursuant to sections 4(e) and 4(f) of the Federal Power Act." Wild and Scenic Rivers, 36 C.F.R. § 297.3, para. 3(a) (1988) (enphasis added).

Preliminary permits thus appear to fall within the provisions both of 36 C.F.R. part 297 and of WSRA section 7. FERC's argument that preliminary permits do not further construction secins unconvincing. It is true that preliminary permits do not inevitably lead to construction; they ouly guarantee priority for eventual hicensing and construction. Nevertheless, the permits do allow study time, and in that way, assist in the construction of water resources projects.

119. Wild and Scenic Rivers, 36 C.F.R. § 297.3, para. 2. 
"Federal assistance" as "[a]ny . . license, permit, or authorization which may be required by an agency or Department of the Federal Government before, during, or after construction of a water resources project." 120 This definition reaches any action requiring federal assistance, including, for example, a federal permit application for a project already built. ${ }^{121}$

The statute does not support Agriculture's position, however. The WSRA's legislative history suggests that Congress intended "construction" to have no more than its plain ineaning. ${ }^{122}$ The conference committee rejected the Senate's language, which referred to "the construction, operation, or mamtenance ... of any dain or other project work."123 It thus appears that Congress intended to prohibit federal aid ouly for the actual fabrication of projects that would adversely affect a wild and scenic river, not to prevent the operation of existing water resources projects. ${ }^{124}$

- Water resources project. The term "include[s] any project that impounds, diverts and returns, or otherwise utilizes water in the river for various purposes." 125 This definition suggests that Congress intended to reach activities requiring Army Corps of Engineers and EPA permits in addition to those regulated by FERC.

- Direct and adverse effect. The requirement prohibits projects that would have a "direct and adverse effect" on a protected river. As before, "direct" means within the boundaries of a wild and scenic (or study) river. ${ }^{126}$ The second sentence of WSRA section 7(a) reinforces this definition by lolding developnients "below or above a wild, scemic or recreational river area" to the

120. Id. \$297.3, para. 3(c) (emphasis added).

121. Agriculture would presumably extend its argument to the "invade or unreasonably diminish" standard. Here Agriculture's case is perhaps stronger, since the statutory language does not explicitly refer to "construction." See WSRA § 7(a), (b), 16 U.S.C. § 1278(a), (b) (1982 \& Supp. IV 1986). The language "[n]othing contained in the foregoing sentence" in each subsection, however, suggests that the restrictions imposed by the clauses that establish the "on or directly affecting" and the "direct and adverse effect" standards will apply to the "invade or unreasonably diminish" standard as well.

122. See generally 114 CONG. REc. 28,313 (1968) (Sen. Nelson's analysis of WSRA section 7 refers to construction as a discrete event).

123. S. 119 , 90th Cong., 1st Sess. § 6(a) (1967), reprinted in 1968 House Hearings, supra note 21, at 21.

124. A new use of an existing project, requiring a federal license, permit, or other aid, would be analogous to construction of a new project; the standard would thus bar that use as well.

125. 114 CONG. REC. at 28,313 .

126. Wild and Scenic Rivers, 36 C.F.R. $\S 297.5(a)(1) ;$ see supra note 103 and accompanying text. 
less stringent "invade or unreasonably diminish" standard. ${ }^{127}$

Even if a project's effect is "direct," the standard demands that it also be "adverse." Although "adverse" is not defined, one can deduce its meaning. In enacting the legislation, Congress undertook to preserve wild and scenic rivers in the same condition as when designated. An adverse effect, then, must be an effect that degrades one of the "values for which such river was established." 128 This definition seems especially rigorous: it bars any project that will have a direct and adverse effect, regardless of magnitude, on a protected river. This contrasts sharply with the standard governing developments below or above a wild and scenic river segment, which only forbids developments that $u n$ reasonably diminish a river's values. ${ }^{129}$

Classification of a river as wild, scemic, or recreational under WSRA section 2(b) sets a threshold for determining "adverse effect." For example, a rustic barn might be acceptable on the shore of a recreational or scemic river, but not on the shore of a wild river, which supposedly represents a "vestige[] of primitive America."130 Because "primitive America" most likely means pre-colonial America, such a barn would be inappropriate. ${ }^{131}$

- Values for which such river was established. This phrase refers to four sets of values derived from the structure and purpose of the

127. WSRA § 7(a), 16 U.S.C. § 1278(a) (Supp. IV 1986) (second sentence). Subsection (b) (regarding study rivers) contains the same language with the addition of the word "potential." Id. $\S 7$ (b), 16 U.S.C. $\S 1278$ (b) (1982 \& Supp. IV 1986) (second sentence).

128. Id. $\S 7(\mathrm{a}), 16$ U.S.C. $\$ 1278$ (a). These values are the ones that inake rivers "outstandingly remarkable." See, e.g., id. § 1, 16 U.S.C. $\$ 1271$ (1982) (declaring policy of preserving "outstandingly reinarkable" rivers); see also supra text accoinpanying note 29 (quoting the section).

129. In this context, it is interesting to reconsider the dispute over preliminary permits. FERC also argues that "[t]he issuance of [a] preliminary permit and any subsequent investigative activities to be accomplished within the river corridor would not disqualify [a river] froin further consideration for inclusion in the [wild and scenic rivers system], nor would the work plan activities hikely create any significant long-term impacts to the environinent." Alaska Power Auth., Project No. 3175-000, 20 F.E.R.C. I 61,398, at 61,808, 61,810 (1982). If this is true of preliminary permits in general, and it likely is, then neither the Department of the Interior nor Agriculture has any practical basis for an objection to preliminary permits.

130. WSRA § 2(b)(1), 16 U.S.C. $\$ 1273(b)(1)$ (1982).

131. Similarly, the Forest Service has developed its "Guidehines for River Recreation Opportunities Manageinent" to assist river administrators in determining appropriate levels of developinent. See UNITEd States Forest SeRV., U.S. DeP'T OF Agric., Forest Service MANUAL tit. 2354.41 exhibit 1 (Jan. 1986) [hereinafter Forest SERviCE MANUAL]. For example, access to wild rivers is restricted to water or trails, and no facilities should be developed "except where absolutely necessary for health, safety and resource protection." Id. 
WSRA. The first is the river's free-flowing condition. ${ }^{132}$ A river should be kept free of such developinents as dams, diversions, and rip-rapping (i.e., rocks laid along river course to slow erosion) and should contain enough water "to maintain its scemc, recreational, and fish and wildlife values."133

The second set of protected values consists of the river's "outstandingly reinarkable" characteristics. These are the characteristics that initially qualify a river for inclusion in the wild and scenic rivers system. The congressional report used to designate the river, or an administering Secretary's report prepared shortly thereafter, should mention these values. ${ }^{134}$ For a study river, these values are those "for which such river might be designated," 135 a considerably broader definition. Congress adopted this broad definition in order to prevent developers from foreclosing the addition of study rivers to the system.

The third set of protected values stems froin the river's classification as wild, scemic, or recreational under WSRA section 2(b). For wild rivers, the WSRA protects those characteristics that make them wild or identify them as "vestiges of primitive America,"136 such as minimal shoreline development and unpolluted water. ${ }^{137}$ Guidelines for scenic and recreational rivers should also be based on the criteria given in the WSRA section 2(b) classification scheme.

The fourth set of protected values includes those features of a river that, although they are not "outstandingly remarkable" and thus do not mandate the river's inclusion in the wild and scenic rivers system, nonetheless appear in Congress's or the Secretary's designating report. Although the standard does not explicitly protect these values, or others that are present in the area of a designated river but not included in the designating report,

132. Congress's policy is to "preserve ... selected rivers or sections thereof in their free-flowing condition." WSRA § 1(b), 16 U.S.C. § 1271(b) (1982). "[F]ree-flowing" is defined in WSRA $\S 15(b), 16$ U.S.C. § 1286(b) (1982).

133. S. Rep. No. 491, 90th Cong., 1st Sess. 11 (1967); see also Forest Service MaNuAL, supra note 131, tit. 2354.03, para. 8 (policy objective of Forest Service is to "acquire water rights needed to ensure sufficient water to achieve management objectives").

134. See WSRA § 3(b), 16 U.S.C. § 1274(b) (Supp. IV 1986) (admininstering Secretary shall "establish detailed boundaries ... [and] detennine which of the classes outlined in [WSRA section 2(b)] best fit the river or its various segments"); see also FoREST SERVICE MANUAL, supra note 131, tit. 2354.04a (obligating Chief of Forest Service to submit data and recominendations on wild and scenic (or study) rivers and to evaluate adverse impact of proposed water resources projects).

135. WSRA § 7(b), 16 U.S.C. § 1278(b).

136. Id. § 2(b)(1), 16 U.S.C. § 1273(b)(1) (1982).

137. See id.; supra note 131. 
the standard should forbid any action that degrades such values to the point where the degradation affects a protected value. ${ }^{138}$

Read as a whole, this standard prohibits any act that would aid the physical construction or modification of a water resources project within the dehneated boundaries of a wild and scenic (or study) river if the administering Secretary determines that the project would have an adverse effect within those boundaries.

Suppose our hypothetical developer nodifies its proposal by substituting an irrigation water intake for Middle Dam. Suppose also that the land to be irrigated falls partly within the wild and scenic river area. The development would still probably violate the "direct and adverse effect" standard. Irrigating land within the river area undoubtedly has a "direct" effect on the area, and although the effect might not be "adverse" on a recreational river, it would be on a wild or scenic one. ${ }^{139}$ The intake inechanisin, however, presents a more difficult problein. The WSRA does protect state water rights; ${ }^{140}$ nevertheless, if the intake withdrew enough water to affect the free flow of a river or the water level of a stream designated for natural beauty, it would violate the standard. ${ }^{141}$

\section{The "Invade or Unreasonably Diminish" Standard.}

Nothing contained in the foregoing standards, however, shall preclude hicensing of, or assistance to, developinents below or above a wild, scenic[, recreational, or study] river area or on any stream tributary thereto which will not invade the area or unreasonably diminish the scenic, recreational, and fish and wildlife values present in the area as of the date of designation of a river as a coinponent of the National Wild and Scenic Rivers Systein. ${ }^{142}$

138. For example, the odor of a sewer dump line in a river with "outstandingly remarkable" sceric beauty may ultimately render that river unviewable, thus adversely affecting its protected value.

139. While irrigating a farm would almost certainly violate the standard for a wild river, see supra note 130 and accompanying text, the issue is less clear for a scenic river. Of course, a visually intrusive center-pivot irrigation system would be inappropriate for a scenic river, which supposedly has "shorelines or watersheds still largely primitive." WSRA § 2(b), 16 U.S.C. § 1273(b).

140. WSRA $\S 13,16$ U.S.C. $§ 1284$ (1982).

141. This result does not necessarily mean that the pipeline would be prohibited. The developer and the determining agency could negotiate to eliminate the project's adverse effects, enabling the project to continue. This strategy is discussed infra notes 160-74 and accoinpanying text.

142. This language is drawn froin the second sentence of WSRA $\$ 7$ (a), 16 U.S.C. $\$ 1278$ (a) (Supp. IV 1986), but substitutes "standards" for "sentence." Similar language appears in subsection (b), except that "potential" precedes "wild, sceric or recreational river area" and the phrase "on the date of designation of a river for study as provided for in section 1276 of this title" concludes the sentence. Id. $\S 7(\mathrm{~b}), 16$ U.S.C. $\S 1278$ (b) (second sentence). The discussion in this section of the Note applies to both subsections (a) and (b). 
The 1968 conference committee added this standard to WSRA section 7 to allay fears that the Act prohibited any development in the same river basin as a wild and scenic river-even beyond the river's boundaries. ${ }^{143}$ In applying this standard, the Secretary of the Interior, or where national forest lands are involved, the Secretary of Agriculture, should consider the following definitions:

- Licensing of, or assistance to. This provision, like the similar provision in the "direct and adverse effect" standard, ${ }^{144}$ should be broadly construed to cover any act that facilitates construction of a water resources project. ${ }^{145}$

- Developments below or above. This phrase stipulates that the standard applies only to those developinents located beyond the boundaries of the wild and scenic or study river but still on the same river or a tributary. Developments within the boundaries of a wild and scenic or study river are governed by the preceding three standards. ${ }^{146}$

- Which will not invade the area. This language refers to encroachment of an impoundment's water into the boundaries of a wild and scenic river area. If the project works "invade" the wild and scenic river area, they are not "below or above" it.

- Unreasonably diminish. This term is the heart of the "invade and unreasonably diminish" standard; it defines the desired balance between the competing interests of preservation and developinent. Unlike the "direct and adverse effect" standard, this standard involves an element of reasonableness. It would allow a project that would have an adverse effect on a river unless the appropriate Secretary determines that the effect is unreasonable. The term "unreasonable" is, of course, broad; it should require the Secretary to consider both the benefits of a proposed project and any diminution it implies for the river's values. An ex-

143. WSRA opponents feared that all developments on a wild and scenic river system would be blocked. See supra notes $25-27,43$, and accompanying text. The conference committee added the "invade or unreasonably dininish" standard for developments outside the wild and scenic river area, noting that the conferees "wanted to'make it clear that these prohibitions [in WSRA section 7(a), (b)] do not apply to upstream or downstream projects which will not unreasonably diminish the values of the river in existence on enactment." 114 CoNG. REc. 28,313 (1968) (statenent of Sen. Nelson).

144. See supra text accompanying note 118.

145. See, e.g., 114 CoNG. REC. at 28,313 ("water resources project" should be construed to include any project that impounds, diverts and returns, or otherwise uses river water).

146. The "below or above" language in this standard suggests that the preceding standards are restricted to actions within the wild and scenic river area. 
tremely beneficial use should therefore be granted more leeway than a less beneficial one.

In determining unreasonable diminution, the appropriate Secretary should also consider the priority of the values being protected. A river's free-flowing status, its "outstandingly reinarkable" values, ${ }^{147}$ and the features that led to its classification should be protected more vigorously than other values. A small degradation of an "outstandingly reinarkable" value may be unreasonable because it implicates the WSRA's statutory purpose to preserve free-flowing rivers with "outstandingly remarkable" characteristics, whereas a relatively greater degradation of a value not implicating that statutory purpose may be reasonable. For example, Congress might designate a river in recognition of its "outstandingly remarkable" muskellunge fishing. The river might also have other values, such as scenic beauty or water quahty, that are not histed as "outstandingly reinarkable." Thus, although the determining agency could possibly permit effluent discharges that would adversely affect the scenic beauty or water quality, the agency could not permit discharges that would adversely affect the muskellunge fishing.

- The scenic, recreation, and fish and wildlife values present in the area. Because the standard protects those values "present in the area," it is broader than the "direct and adverse effect" standard, which protects ouly the values "for which such river was estabhished" (or designated for study). ${ }^{148}$ The "invade and unreasonably diminish" standard seems to include all scenic, recreation, and fish and wildhfe values in the area of a wild and scenic river, even those not specifically mentioned in the designating report used by Congress or the Secretary.

- In the area. Like the other standards, the "unreasonably diminish" standard concerns how developinents affect values within a wild and scenic river area. Unlike the others, however, this standard governs developments located outside a wild and scenic river area. Thus, the standard regulates such a developnent's residual effects within the wild and scenic river area affected; its impact outside that area is irrelevant. For example, the standard would prohibit licensing a paper plant located immediately up-

147. Congress uses "outstandingly remarkable" values to justify designating a river. Examples, cited supra note 30, include extraordinary natural beauty, exceptional water quality, a wide variety of fishing opportunities, or an unusual mix of wildlife.

148. WSRA § 7(a), (b), 16 U.S.C. § 1278(a), (b) (1982 \& Supp. IV 1986). 
stream from a wild and scemic river area if the plant would pollute the water inside the river area.

Read as a whole, this standard prohibits any act aiding the physical construction or modification of a water resources project outside the delineated boundaries of a wild and scemic river if the administering Secretary determines that the project either (1) physically invades the area within the boundaries, or (2) unreasonably diminishes any of the four classes of protected values within the boundaries. The standard permits all other developments outside of the wild and scenic river boundaries.

Returning to our hypothetical, Lower Dam should easily survive under this standard, unless its impoundment was to invade the wild and scenic river area; ${ }^{149}$ such an "imvasion" would obviously violate the standard. Upper Dam is more likely to violate the standard's "unreasonably diminish" provision. The dam's upstream location may cause variance in water flows, water levels, turbidity, or dissolved oxygen levels, and thus unreasonably diminish the river's protected values. In that case, the developer would have to modify the project to eliminate those effects, or else abandon it.

\section{APPLICATION OF THE WIID AND SCENIC RIVERS STANDARDS}

\section{A. General Limitations.}

The primary limitation on the application of the WSRA standards is that the standards only prohibit government assistance to developments; they do not ban developments themselves. ${ }^{150}$ Although in many cases federal assistance is necessary to a project's construction, ${ }^{151}$ such indirect enforcement might be inadequate to prevent harmful changes in the project's subsequent operations. ${ }^{152}$ The standards provide no direct recourse against a licensee, permittee, or other recipient of federal assistance who degrades a wild and scenic river. ${ }^{153}$

149. The standard might also threaten Lower Dam if the river were important as a spawning area for salinon. If Lower Dam restricted the fish's access to the spawning area, it would have a dininishing effect on the river's value and, if the effect were unreasonably diminishing, would violate the standard.

150. Id. $\S 7$ (a), (b), 16 U.S.C. $\S 1278(\mathrm{a}),(\mathrm{b})$.

151. For example, developers often need a FERC license to block navigable waters of the United States. See FPA § 4(d), 16 U.S.C. § 797(e) (1982).

152. For example, a dam operator whose release schedule is not regulated by either FERC or the Army Corps of Engineers might choose to decrease releases to such an extent that spawning gravels are left dry, severely damaging a river that is considered "outstandingly reinarkable" for its salmon fishing.

153. Outside the water resources context, however, an agency, in its capacity as surface owner, could refuse to allow developments inside the river area. See WSRA $\S 12,16$ U.S.C. $\S 1283$ (1982 \& Supp. IV 1986). The administering Secretaries may also be able, under the federal "reserved water 
Various time factors also limit application of the standards. First, none of the standards apply until after a river is designated. Second, the language "for which such river was [or miglit be] designated"154 in the "direct and adverse effect" standard, and the "on the date of designation" language in the "invade or unreasonably diminish" standard, 155 suggest that designation will not prohibit preexisting projects with adverse or diminishing effects on a river. ${ }^{156}$ Third, the determining agency can act only during the pendency of a license or permit application. ${ }^{157}$ Under the "direct and adverse effect" and "invade or unreasonably diminish" standards, however, the Secretary must act during the period of construction and federal assistance. ${ }^{158}$

In sum, the wild and scemic rivers standards limit development only if the project involves: federal action, a preexisting wild and scerric (or study) river, and, for the two judgmental standards, a nexus in time between the federal action and "construction." The absence of any of these conditions will preclude enforcement of the standards.

\section{B. Methods of Application.}

1. Single Preliminary Determinations. The single preliminary determmation is the typical inethod of applying the wild and scemic rivers standards. The method requires that the determining agency ensure a proposed project's compliance witl the WSRA before the project can

rights" doctrine, to object to upstream developments that threaten water flow. See Gray, No Holier Temples: Protecting the National Parks Through Wild and Scenic River Designation, 58 U. CoLo. L. REV. 551 (1988) (arguing that WSRA is as important as Wilderness Act, 16 U.S.C. $\S \S 1131-36$ (1982 \& Supp. IV 1986), in protecting water resources within national parks).

154. WSRA $\S 7($ b), 16 U.S.C. $\$ 1278(b) ;$ see also id. $\S 7(a), 16$ U.S.C. $\S 1278(a)$ (using "estabhished" instead of "desiguated").

155. Id. $\S 7$ (a), (b), 16 U.S.C. $\$ 1278(a),(b)$.

156. Senator Nelson so understood the WSRA's provisions in his section-by-section analysis. With respect to the "invade or unreasonably diminish" standard, he noted that the "prohibitions do not apply to upstream or downstream projects which will not unreasonably diminish the values of the river in existence on enactment." 114 CONG. REC. 28,313 (1968) (emphasis added).

157. The Secretary could not, for example, revoke a FERC license after it has become irrevocable, without paying just compensation. See Appalachian Power Co. v. Umited States, 607 F.2d 935, 940-42 (Ct. Cl. 1979) (examining relation of FPA irrevocability to WSRA), cert. denied, 446 U.S. 935 (1980); cf. FPA § 14(a), 16 U.S.C. § 807(a) (1982) (reserving right of condemnation).

158. Regarding the meaning of "construction," see supra notes 118-24 and accompanying text. Although a Secretary can enforce the standards only during the limited period of construction and federal assistance, the standards presumably prohibit either a determining or authorizing agency from ratifying adverse developments after construction has becn completed. For example, should a project built on a navigable stream of the United States (which would require a license or pernit) have an adverse or unreasonably diminishing effect on a wild and scenic river, the determining agency could not evade the standards by giving the necessary permission after construction of the project had been completed. 
receive a license, permit, or other federal aid. The determining agency may either approve or reject the project.

This approach is well suited to the ministerial standards, which require only a yes-or-no determination of whether a proposed project is "on" a wild and scenic river. The discretionary standards, however, are not anienable to a single all-or-nothing determination. Because all of the standards prohibit only those projects that will have an adverse effect on a protected river, the determining agencies could not adequately dispose, in a single determination, of projects that might have an adverse effect. ${ }^{159}$

2. Conditional Determinations. Because the single-preliminarydetermination approach lacks needed flexibility, the determining agencies have begun to use a "conditional determinations" method, under which an agency will permit a project if a hicensee incorporates certain conditions into its project's operation and design. ${ }^{160}$

The wild and scemic rivers scheme may not permit such conditional determinations, however. Neither the WSRA nor the ECPA expressly allow thenl. Indeed, the ministerial standards prohibit determining agencies from using conditional determinations to evade their obligation to deny a license or exenuption to projects "on or directly affecting" a wild and scenic river. ${ }^{161}$ If a proposed project violates the standards, the agency must reject it. ${ }^{162}$

A better case for the use of conditional determinations can be made under the two discretionary standards. The WSRA's legislative history suggests that conditional determinations may be permissible: "In sonie

159. Take, for example, a proposed project that may have an adverse impact on a wild and scenic river. If forced to inake a single preliminary determination, the determining agency might have to reject the proposal in order to advance the congressional goal of preservation. Yet rejection may frustrate Congress's desire to allow developments below and above a wild and scenic river.

Furthermore, it is unclear that the agency inay reject a proposed project based on its potential adverse impact; the WSRA forbids only projects that will degrade a protected area. WSRA § 7(a), (b), 16 U.S.C. $\S 1278(a)$, (b).

160. See Wild and Scenic Rivers, 36 C.F.R. $\$ 297.5$ (b) (1988) ("If consent is denied, the Secretary [of Agriculture] may recommend measures to eliminate adverse effects, and the authorizing agencies may submit revised plans for consideration."). For example, a Department might permit construction of a proposed project if the developer agreed to maintain minimum flows, build fish ladders, or to take other measures necessary to protect the river's values.

161. See e.g., ECPA, 16 U.S.C. \$ 824a-3(j) (Supp. IV 1986) (prohibiting location of hydroelectric plants on wild and scenic rivers); WSRA § 7(a), (b), 16 U.S.C. $§ 1278(a)$, (b) (prohibiting FERC from licensing projects on wild and scenic rivers).

162. Should the determining agency fail to reject a proposed project that violates the ministerial standards, a suit to compel the agency to reject the project would be possible. The plaintiffs, assuming that they had standing, would need to show only that the proposed project fell within the boundaries of a wild and scenic (or study) river and that FERC had granted a license or exemption. Since FERC's and the Departments' roles are purely ministerial under the first two standards, inandamus would be an appropriate remedy. 
cases ... developments could be permitted if the applicant for the license, etc., mcludes some safeguards or other features in the project to prevent such adverse effects." 163

Conditional determinations have limited utility under the "direct and adverse effect" standard because developments within a desiguated river area directly implicate the congressional policy to preserve wild and scenic rivers within their boundaries. The sweeping definition of "adverse," which prohibits any degradation of a protected value, ${ }^{164}$ would also limit an agency's discretion to craft conditional determinations. Some limited uses of conditional determinations under the "direct and adverse effect" standard, however, are permissible. Rather than sinply rejecting a proposed project witl adverse effects, the determining agency might suggest conditions that would eliminate tlie effects. ${ }^{165}$ If the developer accepted those conditions, and tle authorizing agency incorporated then into the license, permit, or other aid, tle determining agency could then approve the project.

Stronger policy arguments support the use of conditional determinations under the "invade or unreasonably diminish" standard. Congress clearly intended to allow developments "below or above" a wild and scenic river when such developinents do not "unreasonably diminish" the river's values. The determining agency has greater discretion in fasl1ioning conditions under the "invade or unreasonably diminisl1" standard, since that standard protects all values found in a wild and scenic river area, ${ }^{166}$ not merely those values that contributed to the river's designation, as is the case under the "direct and adverse effect" standard.167 Thus, the determining agency can use conditional determinations to bargain with developers, perhaps demanding additional protections for higher priority values, such as the river's "outstandingly remarkable" qualities, in exchange for permitting sonie degradation of lower-priority values. ${ }^{168}$ Sucl an approacl gives the determining agency the flexibility needed to protect critical river values, without imposing the ligil social cost of foreclosing useful projects.

The propriety of conditional determinations ultimately depends on how effectively the determining agency can enforce tle conditions that it

163. 114 CoNG. REC. 28,313 (1968) (statement of Sen. Nelson).

164. See supra notes $128-29$ and accompanying text.

165. This corresponds with the current practice of the administering Secretaries. See, e.g. Wild and Scenic Rivers, 36 C.F.R. 297.5(b) ("If consent is denied, the secretary may recommend measures to eliminate adverse effects, and the authorizing agencies may submit revised plans for consideration.").

166. WSRA § 7(a), (b), 16 U.S.C. $\S 1278(a)$, (b).

167. See supra notes $132-38$ and accompanying text.

168. See $i d$. for a discussion of priorities among values. 
negotiates before approving a project. Such conditions are to an extent self-enforcing, since a project cannot receive any federal assistance without agency approval. If, however, a project adversely affects a protected area or violates a condition after agency approval has been granted, the determining agency is powerless to intervene unless a condition of the license or permit allows direct action against the project operator.

The problem with enforcing such conditions is partially overcoune by FPA section 4(d), which provides:

[L]icenses shall be issued within any reservation only after a finding by the Commission that the license will not imterfere or be inconsistent with the purpose for which such reservation was created or acquired, and shall be subject to and contain such conditions as the Secretary of the departinent under whose supervision such reservation falls shall deem necessary for the adequate protection and utilization of such reservation .... 169

Although this provision provides adequate security under the "direct and adverse effect" standard against developments that are "within" a reservation, it does not provide security under the "invade or unreasonably diminish" standard against developments that are below or above the wild and scemic river, but not "within" a federal reservation. Nor does the provision protect study rivers, which, before they are designated, frequently lack the requisite characteristics of a federal "reservation."170

To solve these enforcement problems, the determining Secretary could petition the authorizing agencies, such as FERC, to place conditions on licenses or permits. FERC, for instance, has extensive authority to require inodifications of project proposals to ensure that they are "best adapted to a comprehensive plan for inproving or developing a water- way . . . and for other beneficial public uses, including irrigation, flood

169. FPA § 4(d), 16 U.S.C. § 797(e) (Supp. IV 1986).

"[R]eservations" means national forests, tribal lands embraced within Indian reservations, military reservations, and other lands and interests in lands owned by the United States, and withdrawn, reserved, or withheld from private appropriation and disposal under the public land laws; also lands and interests in lands acquired and held for any public purposes; but shall not include national monuments or national parks ....

Id. § 3, para. 2, 16 U.S.C. \$796(2) (1982). A wild and scenic river qualifies as a "reservation" because the public lands within the river area are withdrawn from public entry. WSRA $\S 8(a), 16$ U.S.C. $\S 1279$ (a) (1982). Further, the government will have acquired a portion of private lands within the wild and scenic river's ultimate boundaries in fee simple; other private land may be subject to conservation easements. See id. §16(c), 16 U.S.C. \$1286(c) (1982). In either case, the United States will have obtained "an interest" in the land, bringing it within the definition of a "reservation." See, e.g., FPA § 3, para. 2, 16 U.S.C. § 796(2). The administering Secretary can thus impose binding conditions under FPA section 4(d).

170. The protection of study rivers under this provision is less than clear. While an area extending one-quarter of a mile from the river bank is withdrawn from public entry, see WSRA § 8(b), 16 U.S.C. $\S 1279(b)(1982)$, large tracts of land will remain in private ownership and thus outside the language of FPA $\S 4(d), 16$ U.S.C. $\$ 797(e)$. 
control, water supply, recreational and other purposes."171 By designating a river as wild and scenic, Congress establishes preservation of the river's wild, scenic, or recreational character as the use "best adapted" for the river. ${ }^{172}$ FERC therefore may require nodifications of projects below or above the river to preserve the river's "best adapted" use.

Nevertheless, petitioning the authorizing agencies has significant drawbacks. The determining Secretary's suggestions do not bind FERC. ${ }^{173}$ Moreover, the authorizing agencies have exclusive authority to enforce license conditions; ${ }^{174}$ thus, to have any alleged violations imvestigated and corrected, the Secretary must re-petition the authorizing agency.

\section{A Proposal for Legislative Reform.}

The current wild and scenic rivers enforcenient schenie is adequate as far as the two ministerial standards are concerned. It is also adequate for the "direct and adverse effect" standard, at least when binding conditions are available under FPA section 4(d). Once a determining agency has approved a project, however, the scheine inadequately enforces the "invade or unreasonably diminish" standard: the authorizing agency is not obligated to enforce the conditions suggested by the determining agency. This situation could frustrate achieventent of Congress's goal of river preservation. The determining agency, on the other land, niay anticipate the authorizing agencies' failure to enforce license conditions and thus reject potentially beneficial projects. Such rejection could inipede achievement of Congress's goal of balanced development "below and above" wild and scenic rivers.

To resolve these difficulties, Congress slould grant the Secretaries the right to impose on licenses, permits, and other federal aid any conditions necessary to achieve the goals of the wild and scenic rivers progranl. Such conditions might include minimum stream flows, fish ladders, visual screening requirenients for forestry operations, and other measures to reduce a proposed development's impacts on a wild and

171. FPA § 10(a), 16 U.S.C. $\S 803(\mathrm{a})(1)$ (Supp. IV 1986) ("best adapted"); see also id. § 10(g), 16 U.S.C. $\$ 803(\mathrm{~g})(1982)$ ("other conditions not inconsistent"); Niagara Mohawk Power Corp. v. FPC, 379 F.2d 153, 158-59 (D.C. Cir. 1967) (Commission has wide latitude to modify projects in the public interest).

172. Presumably, direct congressional designation overrides FERC's delegated factfinding role.

173. The Secretary's recommendations are mandatory only for projects within the "reservation." See, e.g., FPA § 4(d), 16 U.S.C. § 797(e). Developments "below or above" are beyond the boundaries of the wild and scenic river, even if they affect the river, and hence are outside the "reservation."

174. See, e.g., FPA § 26, 16 U.S.C. $\S 820$ (1982) (FERC and Secretary of the Army are only parties allowed to revoke licenses.). 
scenic (or study) river's protected values. After a hearing, ${ }^{175}$ these conditions should bind the authorizing agencies as an integral part of the license, permit, or other aid. Congress should also permit the Departments to seek injunctive rehef for violations of those binding conditions, ${ }^{176}$ despite any provisions in other legislation limiting enforcement authority to the authorizing agencies. ${ }^{177}$

By adopting such ineasures, Congress would improve the ability of the Departments of the Interior and of Agriculture to achieve the twin goals of river preservation and balanced developinent. In addition, Congress would relieve the Departments from the burden of relying on the cooperation of authorizing agencies. Witl authority to impose binding conditions, the Departments could force developers to accept and maintain certain conditions in order to proceed with their proposed projects. Under the current wild and sceiric rivers regime, the Departments cannot impose sucl conditions; instead, they must gamble on whether a project will actually produce adverse effects, and on whether the authorizing agency will cooperate in enforcing the conditions recommended by the Departments. In addition, under the current scheine the Departments find it difficult to approve projects that might, but not necessarily will, have the adverse effects that the WSRA proscribes. If the Departinents had authority to impose binding conditions on such projects, they could approve them while reducing the risk that adverse effects would occur in the future. In the final analysis, Congress's twin goals of river preservation and balanced development would be better served if the Departments had the authority to inpose and enforce binding conditions.

\section{Conclusion}

In developing the wild and scenic river concept, Congress adjusted the balance of federal water resources policy in favor of river preservation. It chose to protect "outstandingly reinarkable" rivers by limiting the authority of the authorizing agencies to permit and assist development on those rivers.

175. Hearings would serve to prevent the emergence of a pro-preservation bias in the application of the wild and scenic rivers standards. A hearing would require the Departments to justify their decisions to permit proposed projects and explain the need for any proposed binding conditions. Developers could then respond. Hearings would also enable authorizing agencies to intervene, explaining how proposed developments fit into a "comprehensive plan" for river development under the FPA. See supra note 171 and accoinpanying text. In addition, hearings would provide an administrative record for subsequent judicial review.

176. This would allow the Department to enforce the binding condition as long as the license or permit remains in effect, or, in the case of financial aid, for the life of the project.

177. See, e.g., FPA $\S 26,16$ U.S.C. $\$ 820$ (FERC and Secretary of the Army are only parties allowed to revoke licenses). 
To this end, Congress has developed a comprehensive scheme governing water resources developments on the wild and scemic rivers. The standards distilled from that scheme represent the outer limits of agency authority in managing a wild and scemic river. In conjunction with the classifications in WSRA section 2(b), the standards direct agencies' discretion as they balance preservation against permissible development. Agency discretion under the two ministerial standards is limited to determining whether a proposed water resources project falls within the boundaries of a wild and scemic river. The discretionary standards, in contrast, require the determining agencies to exercise their professional judginent in deciding whether to allow a proposed water resources project.

The determining agencies should use the single preliminary determination approach for the ministerial standards and the conditional determinations method (with emphasis on the mandatory conditions under FPA section 4(d)) for the discretionary standards. Furthermore, Congress should grant the determining Secretaries the power to impose binding conditions on all developments that implicate any of the standards. Congress should also permit the Secretaries to directly enforce conditions against hicensees, permittees, and other federal aid recipients, thus relieving the Secretaries of the burden of petitioning authorizing agencies to take enforcement action.

The WSRA and related legislation have become a major force in federal water resources policy. Properly administered, the wild and scenic rivers standards represent a significant step toward the development of a comprehensive national water policy "best adapted" to meeting the nation's need for river preservation and balanced water resources development.

Eric L. Hiser 
